\title{
THE CHALLENGE OF ARID LANDS
}

\begin{abstract}
$A_{\text {CCORDING to definitions of aridity adopted by the }}$ Arid Zone Major Project of Unesco, arid lands occupy 23 per cent of the land surface of the globe. The rapidly increasing pressure of population on the better watered lands has inevitably directed world attention to the less fortunate arid lands. In the vast dry stretches which lie in tho less-developed lands the life of the inhabitants is hard and often precarious and those countries are particularly in need of scientific advice and practical help from the more advanced nations. The United States has the problem of the arid lands - one-third of the total area of the 48 contiguous States or about a million square miles fall into the arid category. The Americans have learnt the hard way: despite porsistent warnings by John Wesley Powell as early as 1878, pioneers took farming techniques from the humid East with the inevitable consequences Powell foretold-soil erosion, dust bowls, ruination of land and people. But that was before modern techniques of water control.
\end{abstract}

It is very fitting that the United States should summarize these hundred years of experience and experimentation as a contribution to the solution of the world problem, and that is precisely what Aridity and Man* sets out to do. When the South-western and Rocky Mountain Division of the American Association for the Advancement of Science met at El Paso in 1951 it set up a Committee on Desert and Arid Zones Research, and in due course this body prepared the report for the Buenos Aires meeting of 1963 sponsored by Unesco.

With a foreword and preface, seventy-two authors have contributed to its twenty-four chapters, sixteen of which are devoted to topics, the other eight being case-histories ranging from the problems of Tucson and Los Angeles to the sad story of typical eroded basins. Each topic chapter is a well-balanced résumé of work in its field with a carefully selected bibliography. After a chapter on the regional setting, Indian adaptations and the historical framework are taken up in turn, then weather, water-use, minerals and energy sources, soils, agriculture, the role of forests, native animals and plants as resources. In a chapter on human factors in desert development, D. H. K. Lee develops his well-known investigations of the direct effects of heat and aridity on human physiology, and stresses some fallacies old and new-for example, that one can become acclimatized to a low intake of fluid. By ignoring modern air-conditioning his results seem at variance with M. E. Garnsey and N. Wollman on economic developments. Population and economic prosperity in the arid south-west have grown at phenomenal rates, far exceeding that in the United States as a whole, but in arid California and the mountainous west rather than in the agricultural great plains. The success of industry and the growth of towns should suggest to many countries that the use of scarce water resources is not necessarily or even primarily for irrigation.

A scientist is apt to judge the problem of arid lands in terms of the control of the physical environment, and it is well that two chapters are devoted to political and social institutions-insufficiently adapted to the environmentand to a critical review of man's history, in which damage

* Aridity and Man: The Challenge of the Arid Lands in the United States. Edited by Carle Hodge, in association with Peter C. Duisberg. Pp. Xx+ 584. (Publication No. 74.) (Washington,
the Advancement of Science, 1963.) n.p. to the environment has often exceeded improvement. As H. E. Dregne says in his chapter on soils, "recognition that the soils of the arid regions must be managed differently from those of the humid regions came slowly and at great personal cost to the first settlers". The same is, indeed, true of the relationships between man and all the factors of the arid environment, and it is in the now frank recognition of this that lies the particular value of Aridity and Man, acknowledging that much work remains to be done.

The Committee on Desert and Arid Zones Research has sponsored a series of annual oonferences-that in 1960 dealt with "Water Yield in Relation to Environment in the Southwestern United States". Edited by B. H. Warnock and J. L. Gardner, eight contributed papers have been published as a pamphlet $\uparrow$ and the water yield is contrasted for alpine vegetation, pinyon-juniper, oak woodland, grassland and phreatophytic vegetation, as well as being related to cover, soils, and storm patterns. The papers serve to emphasize the curse of irregularity and the difficulties of maintaining anything approaching a steady water yield or even of improving existing conditions. Some interesting examples of snow-storage are given.

More than 60 per cent of the small State of Israelsome 12,500 square kilometres or 5,000 square miles out of a total area less than that of Wales-is arid land. The greater part is, indeed, uncompromising desert, the Negev, which occupies the triangular extension in the south between Egypt on the west and Jordan on the east, with a tiny stretch of Red Sea coast as an outlet in the south. In no country does the development of its desert land present such a vital and challenging problem. Nowhere has desert research been attacked with greater vigour and skill. Jewish scientists from many countries migrated to Israel, taking with them the knowledge, theoretical and practical, of arid lands the world over. They pooled the information from many lands and in many languages, so that research began where other countries left off. Under the auspices of the Anglo-Israel Association, Miss Ruth Halliday, who graduated as a biologist from Newnham in 1961, went to Israel as Wyndham Deedes Scholar, and has written an excellent account of her studiest. In the Negev, south of Beersheba, gateway to the desert, are remains of early settlements which, even allowing for possible climatic changes, seem to have mastered the art of concentrating the slight precipitation over a considerable catchment area to nourish a few fields. She takes the story from there to the present day and looks to the future, but unfortunately gives no references. Outstanding among Israeli achievements is the piping of irrigation water, first from small streams in the humid north, now from the Sea of Galilee. The system has many advantages: no loss from evaporation, perfect control over the exact quantity of water to be released and when. In contrast, great conventional works such as the Aswan High Dam face evaporation losses up to 60 per cent and a less efficient control over distribution.

L. Dúdrey Stamp $\dagger$ Water $Y$ ield in Relation to Enviromment in the Southwestern United States.
Edited by B. H. Warnock and J. L. Gardner. Pp. 128. (Alpine, Texas: Su 1 Ross State College, 1964.)

$¥$ The Skills to Make the Desert Bloom. (Some Aspects of Biological Science in relation to the Negev.) Report by Ruth Halliday. Pp. 49. Anglo-Israe Association Pamphlet No. 4. (London: The Anglo-Israel Association,
1984.) 58. [See also Nature of May 30, p. 843.] 